\title{
Diversity, Abundance, and Traditional Uses of Asteraceae Species in Mount Bisma, Dieng Plateau, Kejajar, Wonosobo, Central Java
}

\author{
Bima Kurniawan ${ }^{1}$, Purnomo², Rina Sri Kasiamdari2* \\ 1)Faculty of Biology, Universitas Gadjah Mada, Jl. Teknika Selatan, Sekip Utara, Sinduadi, Mlati, Sleman, Special Region of \\ Yogyakarta 55281, Indonesia \\ 2)Laboratory of Plant Systematics, Faculty of Biology, Universitas Gadjah Mada, Jl. Teknika Selatan, Sekip Utara, Sinduadi, Mlati, \\ Sleman, Special Region of Yogyakarta 55281, Indonesia \\ * Corresponding author, email: rkasiamdari@ugm.ac.id
}

\author{
Keywords: \\ abundance \\ Asteraceae \\ Dieng Plateau \\ ethnobotany \\ species diversity \\ Submitted: \\ 23 June 2021 \\ Accepted: \\ 24 September 2021 \\ Published: \\ 09 February 2022 \\ Editor: \\ Miftahul Ilmi
}

\begin{abstract}
Asteraceae is the largest and most diverse family of flowering plants which contains more than 20,000 species distributed in nearly all types of habitats all over the world. In mountainous regions such as Mount Bisma, it is estimated to have plenty and diverse member of the Asteraceae family, and used in the local community for various uses. This research aimed to understand the diversity, abundance, and uses of Asteraceae members that are found wild in Mount Bisma. Taxonomy and ecological data were gathered using an exploration method and purposive sampling method, from the point, a plot measured $3 \times 3 \mathrm{~m}^{2}$ was created to estimate the vegetation parameters in the mountain top and mountain valley area. Ethnobotanical data were gathered in Sikunang Village, a nearby village of Mount Bisma using a semi-structured interview and open-ended questions. Data were analysed descriptively and quantitatively using several indices such as Importance Value Index (IVI), Index of Cultural Significance (ICS), and index of Use Value (UV). The result showed that there were 18 species from two subfamilies that grew wild in both mountain top and valley of Mount Bisma. The highest importance value belonged to Ageratina riparia, which was scored in the mountain top and valley 71.00 and 91.53, respectively. Uses of Asteraceae in Sikunang were varies, ranging from being a side dish, medicine, firewood, souvenir, and other uses. Galinsoga parviflora and Galinsoga quadriradiata showed the highest ICS value of 41, whereas Austroeupatorium inulifolium scored the highest in UV of 1.8. The study presented high number of Asteraceae diversity and use. Thus, implies that Mount Bisma has vast unexplored biodiversity and locals around Mount Bisma have rich traditional knowledge.
\end{abstract}

Copyright: C 2022, J. Tropical Biodiversity Biotechnology (CC BY-SA 4.0)

\section{INTRODUCTION}

Asteraceae Bercht. \& J.Presl (1820); synonym Compositae Giseke (1763), nom. cons. is the largest and most diverse family of Angiospermae, composed of ca. 24,000 species from about 1,700 genera that are distributed in nearly all types of habitats all over the world except Antarctica, composing about 10\% of recorded diversity of flowering plants (Funk et al. 2009; Tadesse 2014). Member of Asteraceae are undoubtedly widespread due to its highly adaptive characteristics and the specific feature of their flower; a cluster of numerous 
tiny flowers (florets) called capitula attractive enough to attract a pollinator, self-pollinating mechanisms of the floret, specific type of fruit called achene that is light enough to be dispersed by wind, supported by the presence of pappus (Bhattacharyya 2016; Purnomo et al. 2016).

A high number of Asteraceae species was considered not proportional with the number of beneficial species from the family. Smaller families, e.g. Poaceae or Fabaceae contain more useful plants than Asteraceae (Funk et al. 2009). In general, members of Asteraceae already used for food (Lactuca sativa L., Helianthus tuberosus L.), medicine (Artemisia absinthium L., Taraxacum officinale Wigg.), insecticides (Tanacetum cinerarïfolium (Trev.) Sch. Bip.), and ornamentals (Chrysanthemum indicum L.) (Simpson 2009). A high number of Asteraceae species presents in previous studies are generally acknowledged as a weed. The surrounding community managed to mow the weed because it disturbs the growth of cultivated plants. On the other hand, the surrounding community also finds benefits of Asteraceae species, such as food and medicine. Generally speaking, Asteraceae species are only known to be secondary material as food or medicine, not as the first choice. On the other hand, members of Asteraceae are also recognized as invasive in Indonesia, e.g. Ageratum conyroides L., Galinsoga parviflora Cav., Mikania micrantha Kunth., and Sonchus oleraceus L. (Setyawati et al. 2015) and could affect the survival of native species. Traditional uses of Asteraceae in the local community in unexplored locations need to be researched in order to enrich knowledge on its uses.

Mount Bisma located in Dieng Plateau, Wonosobo, Central Java with a peak reached 2,365 masl, is a volcano, but the volcanic activity is decreased and leaving a wide caldera (Nurpratama et al. 2015). Recently, Mount Bisma is known to be located outside the potential geothermal energy sectors (Harijoko et al. 2016). Mount Bisma was not open for tourist attraction until 2019, thus the mountain has preserved the ecosystem of mountainous region biodiversity. Local communities on Mount Bisma, especially in Sikunang Village, are Javanese, male and female residents mostly work as a farmer, with potato and varieties of vegetables being main crops. Biodiversity and local knowledge of plants in Mount Bisma has not been reported before, especially for the Asteraceae family. Studies on Asteraceae were conducted by Sunarto et al. (2017) in Mount Lawu, Megawati et al. (2017) in Lore Lindu National Park, and Al Farishy \& Salamah (2021) in Mount Halimun-Salak. All of the studies conducted before provided general information on Asteraceae diversity in mountainous regions. With the largest number of species, it is highly potential to find any of the beneficial species of Asteraceae. Wonosobo itself offers attractive natural tourism, with edelweiss, Anaphalis longifolia, being one of the Asteraceae species that is most attractive for tourists. Local archival research on ethnobotany around Mount Bisma is spoken between generations. There is no known archive of ethnobotany in communities around Mount Bisma. In addition, there is also no known research conducted in the surrounding communities as well. The research aimed to explore 
the diversity, abundance, and traditional uses/knowledge about Asteraceae species in Mount Bisma. The result hopefully could present the newest record on the diversity, abundance, and local knowledge of Asteraceae for further research in the future.

\section{MATERIALS AND METHODS}

\section{Materials}

The materials used in this research were plant specimens collected from two research areas of Mount Bisma; Mountain Top (MT) and Mountain Valley (MV), $300 \mathrm{gr} / \mathrm{m}^{2}$ acid-free mounting paper sized A3, alcohol 70\%, ziplock plastic bag sized 40x30 cm, herbarium envelope, label, document-grade scotch tape, and PVA glue 90\%. The tools used in this research were stationary, camera, board, cardboard, voice recorder, and GPS mobile.

\section{Methods}

\section{Study area and period}

The research was carried out in Mount Bisma, administratively located in Sikunang Village, Kejajar, Wonosobo. The village is located at 7014'06" S and 109053'54" E, inhabited by Javanese people, who mainly talk Javanese language with a Banyumasan accent. Mostly, locals are moslem and work as a farmer. Field observation was carried out into two designated areas; Mountain Top (2,365.44 masl) and Mountain Valley (1,599.21 masl). The plot was carried out at two different heights because altitude influences the environment around the plants, limits the growth of certain species and their distribution. Mountain Top following the hiking trails, Mountain Valley started at the intersection between the local's farming area and forest of the valley. Map of the study area presented in Figure 1, red line for MT and blue line for MV. The research was conducted in February 2021 and March 2021.

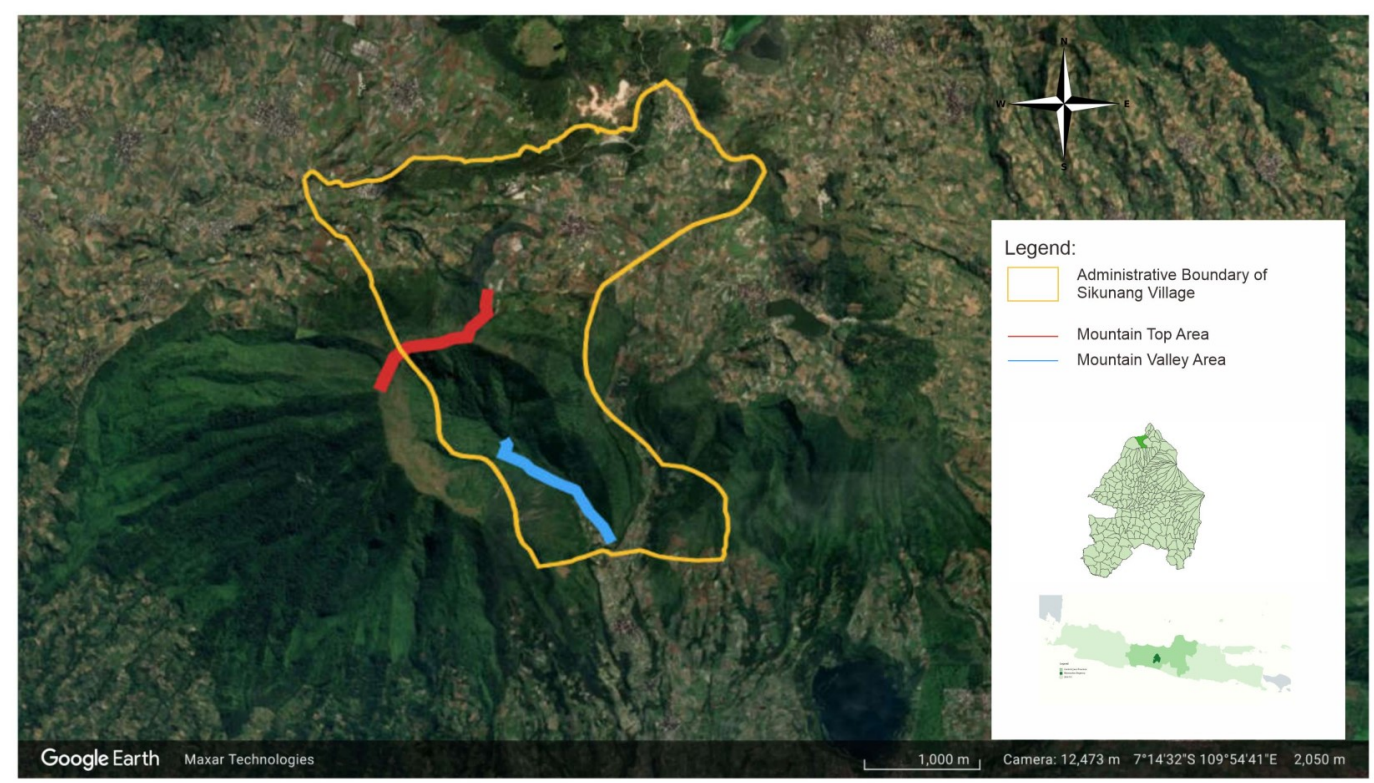

Figure 1. Map of study area showing Sikunang Village administrative boundary (yellow line), Kejajar, Wonosobo, Central Java. Source: Google Earth, 2021. 
Field observation and species identification

Field observation aimed to gather the taxonomy and ecological data. The exploration method was used to gather taxonomical data (Rugayah et al. 2004). Purposive sampling was used to find the location that represents Asteraceae diversity following the designated area, then from each point, a $3 \times 3 \mathrm{~m}^{2}$ plot was made to collect vegetational data, such as a number of species and frequency (Partomihardjo \& Rahajoe 2004). A total of 9 plots and 12 plots were made in Mountain Top and Mountain Valley, respectively. Plant samples for each species were taken to make voucher specimens for further identification. The data then were brought to Laboratory of Plant Systematics, Faculty of Biology UGM for voucher specimen construction (Sardiwinata et al. 2008); identification was based on determination key from Flora of Java (Backer \& Brink 1965), description and illustration from Mountain Flora of Java (van Steenis 2006).

\section{Interview}

The village community survey was used to gather the informants, who are the residents of Sikunang Village, purposive snowball sampling was chosen to found informants with the village chief as a key informant (Silalahi 2016). The respondents are adults (more than 18 years old) from various professions. A total of 15 respondents, mostly by the suggestion of the Village Chief, were interviewed. Fifteen respondents are considered accurate because all of them were chosen by recommendation of a key informant so that all the informants know very well about plants around the village. A semistructured interview with open-ended questions was performed to gather information from informants (Walujo 2004). The interview was equipped with pictures of Asteraceae species found in Mount Bisma.

\section{Data analysis}

Asteraceae species were grouped by taxa, scientific names were rechecked based on Classification of Compositae (Funk et al. 2009) and Global Compositae Database (CWG 2021). The characteristics of invasiveness were determined based on the Guide to Invasive Plant Species in Indonesia (Setyawati et al. 2015). Ecological data in the form of relative density and relative frequency were further analysed by Importance Value Index (IVI) analysis (Barbour et al. 1987). The interview data were analysed to estimate the valuation of the index of cultural significance respective to the categorization of uses (ICS) (Turner 1988), along with the Use Value (UV) analysis (Walujo 2004; Cotton 1996) as general quantification on ethnobotanical data to represent how beneficial a species is for a community.

\section{RESULTS AND DISCUSSION}

Asteraceae Diversity

Study of species diversity on Asteraceae family in hiking trails (mountain top) and mountain valley of Mount Bisma was carried out. Based on Funk et al. 
(2009), a total of 18 species under 16 genera, eight tribes, and two subfamilies were collected and identified. All species were considered wild. Based on the data obtained, out of the 18 species found in the research location, 17\% were recorded only in Mountain Top (MT); 55\% were recorded to be present in both locations (MT and MV); and 28\% were recorded only in Mountain Valley (MV) (Table 1). The species found only in Mountain Top; Anaphalis longifolia, Erigeron karvinkianus, and Leucanthemum vulgare were known to inhabit slope ground and unshaded areas. A. longifolia was known to be typical to grow in the mountain region of Java (van Steenis 2006), the species also found in Mount Lawu and attract tourism activity (Sunarto et al. 2017).

Table 1. Diversity of Asteraceae in Mount Bisma.

\begin{tabular}{|c|c|c|c|c|c|}
\hline No. & Species & Subfamily & Tribe & $\begin{array}{l}\text { Location } \\
\text { Found }\end{array}$ & $\begin{array}{l}\text { Specimen Voucher } \\
\text { Number }\end{array}$ \\
\hline 1 & Artemisia vulgaris $\mathrm{L}$. & Asteroideae & Anthemideae & $\mathrm{MV}, \mathrm{MT}$ & $\begin{array}{l}\text { 13/BA/1, 30/BB/10, 64/ } \\
\mathrm{BB} / 8,68 / \mathrm{BB} / 11\end{array}$ \\
\hline 2 & Leucanthemum vulgare Lam. & Asteroideae & Anthemideae & MT & $41 / \mathrm{BA} / 3$ \\
\hline 3 & $\begin{array}{l}\text { Dichrocephala integrifolia } \\
\text { (L.f.) Kuntze }\end{array}$ & Asteroideae & Astereae & $\mathrm{MV}, \mathrm{MT}$ & $\begin{array}{l}\text { 02/BA/1, 52/BA/1, 69/ } \\
\mathrm{BB} / 11\end{array}$ \\
\hline 4 & Erigeron karvinskianus DC. & Asteroideae & Astereae & MT & $\begin{array}{l}\text { 14/BA/9, 15/BA/8, 46/ } \\
\mathrm{BA} / 7\end{array}$ \\
\hline 5 & Erigeron sumatrensis Retz. & Asteroideae & Astereae & $\mathrm{MV}, \mathrm{MT}$ & $\begin{array}{l}01 / \mathrm{BA} / 1,47 / \mathrm{BA} / 2,67 / \\
\mathrm{BB} / 10\end{array}$ \\
\hline 6 & Bidens pilosa $\mathrm{L}$. & Asteroideae & Coreopsideae & $\mathrm{MV}, \mathrm{MT}$ & $\begin{array}{l}\text { 04/BA/1, 09/BA/9, 10/ } \\
\mathrm{BA} / 1,12 / \mathrm{BA} / 5,33 / \\
\mathrm{BB} / 9,36 / \mathrm{BB} / 11,42 / \\
\mathrm{BA} / 2,62 / \mathrm{BB} / 7\end{array}$ \\
\hline 7 & Ageratum conyzoides L. & Asteroideae & Eupatorieae & MV & $73 / \mathrm{BB} / 12$ \\
\hline 8 & $\begin{array}{l}\text { Ageratina riparia (Reg.) } \\
\text { R.M.King \& H.Rob }\end{array}$ & Asteroideae & Eupatorieae & $\mathrm{MV}, \mathrm{MT}$ & $\begin{array}{l}05 / \mathrm{BA} / 1,07 / \mathrm{BA} / 9,08 / \\
\mathrm{BA} / 9,16 / \mathrm{BA} / 9,24 / \\
\mathrm{BB} / 3,25 / \mathrm{BB} / 1,26 / \\
\mathrm{BB} / 1,39 / \mathrm{BB} / 3,48 / \\
\mathrm{BA} / 1,53 / \mathrm{BA} / 9,54 / \\
\mathrm{BA} / 8,57 / \mathrm{BB} / 1,58 / \\
\mathrm{BB} / 4,59 / \mathrm{BB} / 5,60 / \mathrm{BB} / 3\end{array}$ \\
\hline 9 & $\begin{array}{l}\text { Austroeupatorium inulifolium } \\
\text { (Kunth.) R.M.King \& } \\
\text { H.Rob. }\end{array}$ & Asteroideae & Eupatorieae & $\mathrm{MV}, \mathrm{MT}$ & $\begin{array}{l}03 / \mathrm{BA} / 7,45 / \mathrm{BA} / 2,55 / \\
\mathrm{BB} / 1,56 / \mathrm{BB} / 2,61 / \mathrm{BB} / 6\end{array}$ \\
\hline 10 & Anaphalis longifolia DC. & Asteroideae & Gnaphalieae & MT & $\begin{array}{l}06 / \mathrm{BA} / 5,18 / \mathrm{BA} / 9,21 / \\
\mathrm{BA} / 9,49 / \mathrm{BA} / 13\end{array}$ \\
\hline 11 & Gnaphalium purpureum L. & Asteroideae & Gnaphalieae & $\mathrm{MV}, \mathrm{MT}$ & $37 / \mathrm{BB} / 10,51 / \mathrm{BA} / 1$ \\
\hline 12 & $\begin{array}{l}\text { Acmella paniculata (Wall ex. } \\
\text { DC.) R.K.Jensen }\end{array}$ & Asteroideae & Heliantheae & MV & $32 / \mathrm{BB} / 10,63 / \mathrm{BB} / 9$ \\
\hline 13 & $\begin{array}{l}\text { Tithonia diversifolia (Hemsl.) } \\
\text { A.Gray }\end{array}$ & Asteroideae & Heliantheae & MV & $40 / \mathrm{BB} / 12$ \\
\hline 14 & Galinsoga parviflora Cav. & Asteroideae & Millerieae & $\mathrm{MV}, \mathrm{MT}$ & $\begin{array}{l}\text { 11/BA/1, 27/BB/9, 28/ } \\
\mathrm{BB} / 9,29 / \mathrm{BB} / 10,31 / \\
\mathrm{BB} / 10,34 / \mathrm{BB} / 10,35 / \\
\mathrm{BB} / 11\end{array}$ \\
\hline 15 & $\begin{array}{l}\text { Galinsoga quadriradiata } \\
\text { Ruiz. \& Pav. }\end{array}$ & Asteroideae & Millerieae & MV & $65 / \mathrm{BB} / 11$ \\
\hline
\end{tabular}


Table 1. Contd.

\begin{tabular}{|c|c|c|c|c|c|}
\hline No. & Species & Subfamily & Tribe & $\begin{array}{l}\text { Location } \\
\text { Found }\end{array}$ & $\begin{array}{l}\text { Specimen Voucher } \\
\text { Number }\end{array}$ \\
\hline 16 & $\begin{array}{l}\text { Crassocephalum crepidioides } \\
\text { (Benth.) S. Moore }\end{array}$ & Asteroideae & Senecioneae & $\mathrm{MV}, \mathrm{MT}$ & $\begin{array}{l}\text { 19/BA/1, 22/BA/1,38/ } \\
\mathrm{BB} / 11,71 / \mathrm{BB} / 11\end{array}$ \\
\hline 17 & Sonchus oleraceus L. & Cichorioideae & Cichorieae & $\mathrm{MV}, \mathrm{MT}$ & $\begin{array}{l}\text { 43/BA/3, 44/BA/4, 50/ } \\
\mathrm{BA} / 1,66 / \mathrm{BB} / 10,70 / \\
\mathrm{BB} / 12\end{array}$ \\
\hline 18 & Youngia japonica (L.) DC. & Cichorioideae & Cichorieae & MV & $72 / \mathrm{BB} / 12$ \\
\hline
\end{tabular}

Two subfamilies found wild in Mount Bisma were Asteroideae and Cichorioideae. There are informal categories in the Asteroideae subfamily, the Heliantheae allies. From the subfamilies, it was recognized that seven tribes were classified into Asteroideae (four tribes included in Heliantheae allies) and one tribe classified into Cichorioideae. The diversity of Asteraceae species found in Mount Bisma were similar to other research done in mountainous regions of Sulawesi and Mount Lawu (Megawati et al. 2017; Sunarto et al. 2017). Asteroideae leads in the number of species found because Asteroideae is the largest and most diverse subfamily of Asteraceae (Funk et al. 2009). Most species found in the research are considered invasive alien species (IAS), about 13 out of 18 are considered as IAS, four species known to be alien species, and only one species is recognized distributed naturally in Java. The majority of IAS and alien species are originated in New World (Tropical, North, or South America), the rest of them originated from Old World: C. crepidioides and B. pilosa (Africa); A. vulgaris, L. vulgare, S. oleraceus (Europe and Russia Far East); and two species originated in Asia: D. integrifolia and Y. japonica (Setyawati et al. 2015). The diversity of flower morphology of wild Asteraceae species found in Mount Bisma is presented in Figure 2.

\section{Asteraceae Abundance}

The abundance of Asteraceae species found was determined by the value of the Importance Value Index (IVI). The highest IVI in both locations, MT and MV was obtained from species of Ageratina riparia with IVI $71.00 \%$ and $91.53 \%$, respectively. The result showed that A. riparia was dominated the area with the most number of individuals and presented in the most study plot. A. riparia covered most of the forest floor in MT and MV. Figure 3 and figure 4 showed the IVI for each species found in MT and MV where the IVI does not distribute equally, two species (A. riparia and Austroeupatorium inulifolium) have prominent IVI compared to other species; statistically signs that the coverage of both species are considered high, meanwhile, the other species showed low IVI compared to the dominating species. A. riparia was recognized to be invasive alien species and dominate the forest floor of several mountainous areas of Java; the IVI scored $69.418 \%$ and $81.35 \%$ in Mount Lawu and Dieng Plateau (Mount Alang and Mount Klaras), respectively (Setyawati et al. 2015; Sunarto et al. 2017; Abdiyani 2008). 


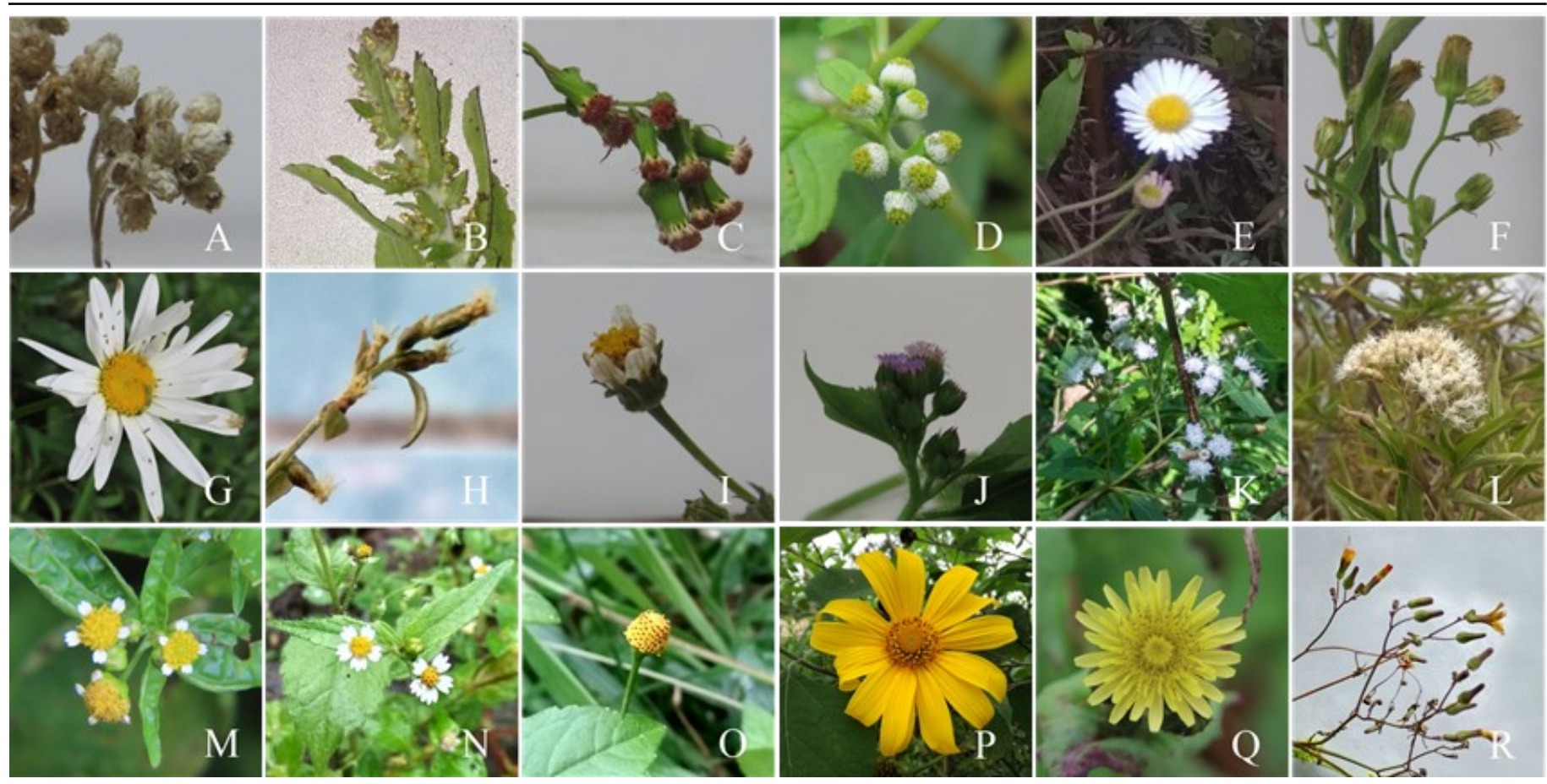

Figure 2. Species of Asteraceae found wild in Mount Bisma. A - H. Asteroideae (without Heliantheae alliance): Gnaphalieae: Anaphalis longifolia, Gnaphalium purpureum; Senecioneae: Crassocephalum crepidioides; Astereae: Dichrocephala integrifolia, Erigeron karvinskianus, Erigeron sumatrensis; Anthemideae: Leucanthemum vulgare, Artemisia vulgaris. I - P: Asteroideae (Heliantheae alliance): Coreopsideae: Bidens pilosa; Eupatorieae: Ageratum conyzoides, Ageratina riparia, Austroeupatorium inulifolium; Millerieae: Galinsoga parviflora, Galinsoga quadriradiata; Heliantheae: Acmella paniculata, Tithonia diversifolia. Q - R: Cichorioideae: Cichorieae: Sonchus oleraceus, Youngia japonica. Source: Personal Documentation, 2021.

The diversity and distribution at different altitudes are relatively different. In Mountain Valley, the area with lower altitude, the species richness counted was more than that of Mountain Top (14 species in MV, 12 species in MT). There is one species that is dominant in both locations, Ageratina riparia, IVI of MV is higher (91.53\%) than in MT (71.00\%), so the A. riparia is considered more dominant in MV than in MT. Even though had more number species, the dominance of $A$. riparia compared to the other species in MV made MV had lower diversity and distribution, which showed that in MT (higher altitude) it is considered more diverse and the species are distributed more evenly. Asteraceae found in higher altitudes, such as Anaphalis longifolia and Erigeron sumatrensis are observed to have special adaptation in terms of its morphological character, i.e. adapted to grow well in cliff/ sloping ground; have narrow leaves, drier stem, and strongly attached to the ground. In lower altitudes, the species generally have a wider and thinner leaf, grows perpendicular to the substrate, and wetter stem.

Ageratina riparia was known to be common in Java mountainous region (Purnomo et al. 2016). The invasiveness of A. riparia was categorized as high risk, A. riparia even had the highest Risk Index in Mount Papandayan. $A$. riparia has an uncommon feature of Asteraceae, that is the species could grow well in shaded areas. Coverage of $A$. riparia was very wide due to the fastgrowing characteristics of the plant, even it is considered very fast compared to other invasive species. On the other hand, the species is also a productive 


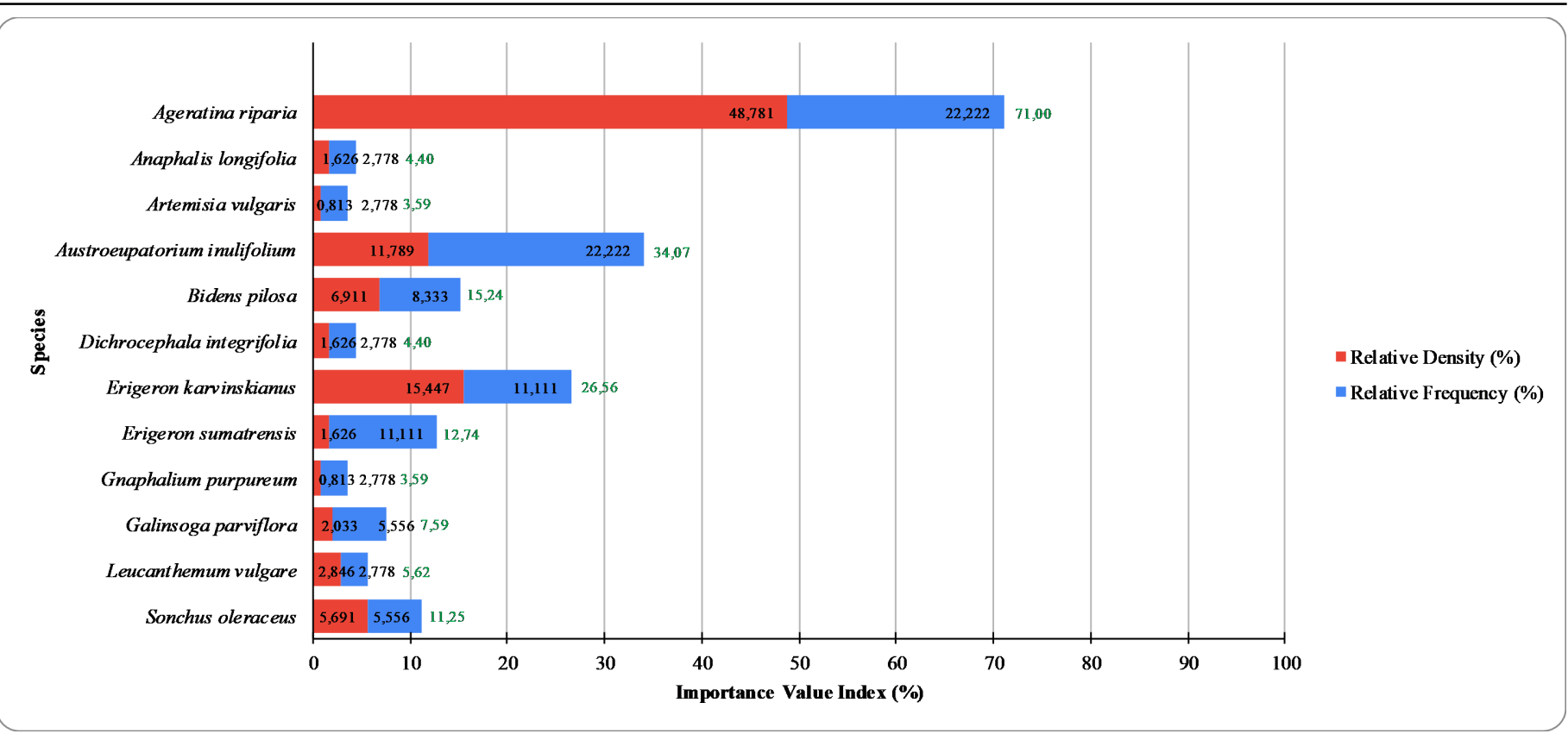

Figure 3. Importance Value Index (IVI) from Mountain Top (MT) Area. Number showed in green symbolized the summation of Relative Density and Relative Frequency (Importance Value Index).

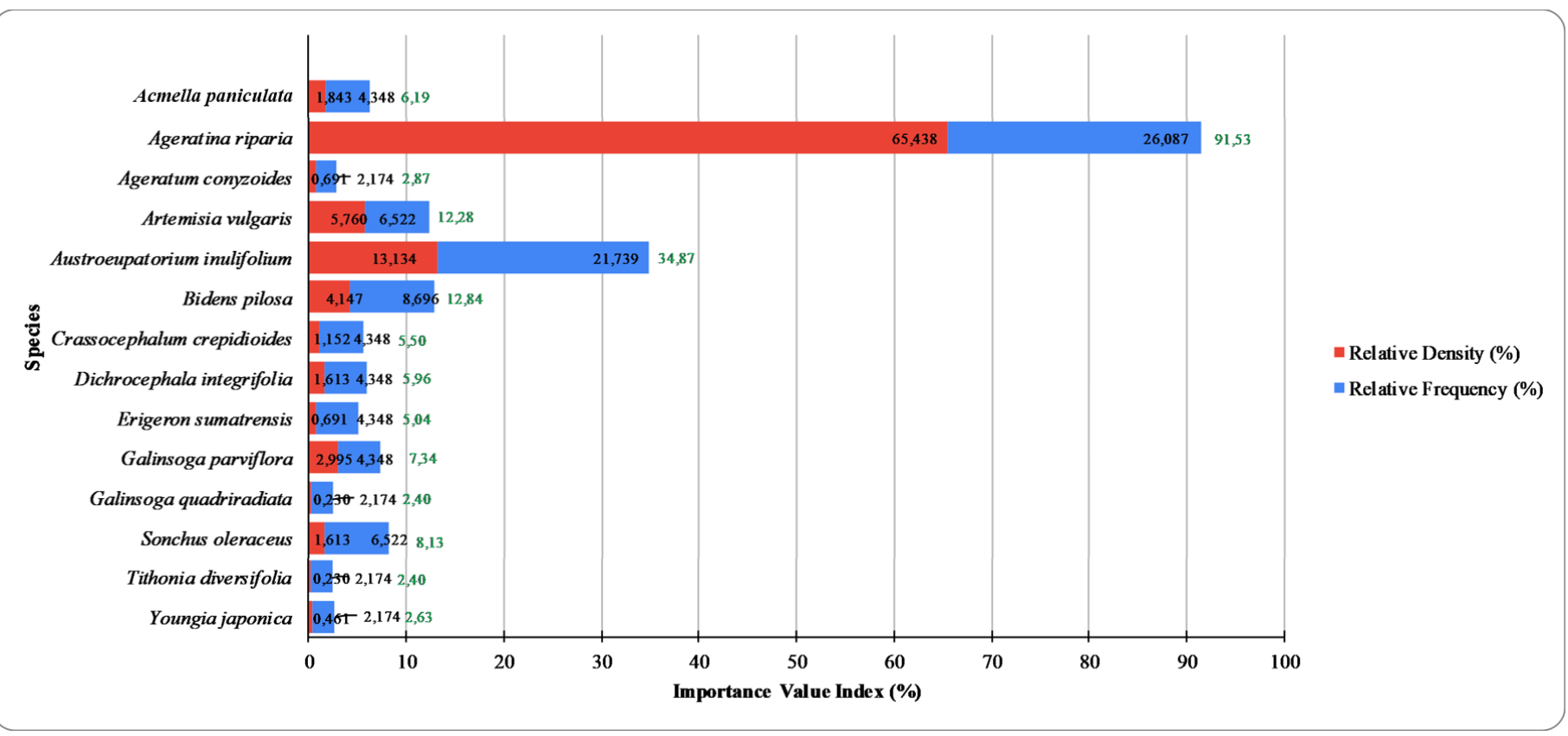

Figure 4. Importance Value Index (IVI) from Mountain Valley (MV) Area. Number showed in green symbolized the summation of Relative Density and Relative Frequency (Importance Value Index).

seeder (Nyuanti et al. 2020). A combination of the characteristics leads the species to invade an area, growing rapidly and dense to dominate the area so that the other species do not have enough space and resources to grow adequately.

\section{Asteraceae Uses}

Locals of Sikunang Village, a nearby village of Mount Bisma were interviewed and the result showed that locals had vast knowledge of plant uses in their household; the uses from 17 out of 18 species of Asteraceae found were recognized by the locals. Locals in Sikunang Village perceive the 
majority of Asteraceae species found as weed, disturbed their field. Several people also recognized species that grow in the upper part of Mount Bisma, inside the forest, and far from their field. However, locals not only mentioned the species as weeds. Local uses of the plant as told by the people and the valuation of ICS and UV are presented in Table 2.

Locals mentioned that several species could be utilized for consumption, medicine, daily needs, livestock forage, to be sold, etc. Even though locals perceive Asteraceae members in general as weeds, the utilization is a sign that locals have a well-understanding in plant uses. Locals in Sikunang Village maintain vegetation amid their mountainous environment, especially in Asteraceae members, make it possible for them to explore any utilization of plants. Plants mentioned used by locals have an opportunity as bioprospection in the future, because the plants are abundant and the benefits are varied, e.g. G. parviflora and G. quadriradiata as delicacies, C. crepidioides as cosmetics, L. vulgare as insecticides. Other bioprospection of Asteraceae members mentioned by locals is $S$. oleraceus (gembos) as rabbit forage. Some of the locals mentioned that rabbit which fed using a mixture of grass, rabbit pellets, and gembos produced better urine quality than rabbit which fed without mixture of gembos, that is highly beneficial as biofertilizer.

The quantification of ICS was based on the quality, intensity, and exclusivity of plant's uses (Turner 1988). The highest score of ICS was obtained by mondrengan or G. parviflora and G. quadriradiata with a score reached 41, that most locals told that the plant could be eaten just raw or cooked. Sendura (A. longifolia) scored second in ICS (36) because of the valuation of the flower, a rare plant with high demand in tourism attraction. Gembos (S. oleraceus) scored third highest of ICS (30) because of their utilization as food, high quality rabbit forage, even some medicinal properties. Meanwhile, malenggo (A.inulifolium) scored fourth highest of ICS (24) because it serves the daily needs of locals as easy-accessed firewood, livestock forage, and economic-importance fragrant flower. On the other hand, UV represents various types of uses known by the locals (Walujo 2004). Malenggo (A. inulifolium), mondrengan (G.parviflora and G. quadriradiata), sendura (A. longifolia), and lengko ( $C$. crepidioides) relatively had high scores compared to other species found in Mount Bisma because various uses are recognized by most locals, meanwhile, the species which had a low score in $\mathrm{UV}$ means that the utilization is not as much as the other species or the utilization varies, but only known to the minority of locals (Cotton 1996). As mentioned in the beginning, most species are known as weeds and disturbing cultivated plants, therefore if locals do not utilize the plant for a specific activity, commonly seen plants will be used as livestock forage, e.g. D. integrifolia and E. sumatrensis. G. purpureum is an uncommon plant for locals; locals do not recognize the plant and therefore the utilization is unclear for locals. High UV or ICS value suggests that the species is more beneficial than other species. If the species is beneficial enough to be demanded by more people, the species tend to be cultivated by people, then it will preserve in 
Table 2. Local name, traditional uses, ICS, and UV for each species of Asteraceae species found in Mount Bisma.

\begin{tabular}{|c|c|c|c|c|c|}
\hline No. & Species & Local Name & Traditional Uses & ICS* & $\mathrm{UV}^{* *}$ \\
\hline $\begin{array}{l}1 \\
2\end{array}$ & $\begin{array}{l}\text { Galinsoga parviflora Cav. } \\
\text { Galinsoga quadriradiata } \\
\text { Rez. \& Pav. }\end{array}$ & $\begin{array}{l}\text { Mondrengan, Jarinten, } \\
\text { Jangkungan }\end{array}$ & $\begin{array}{l}\text { Young leaves eaten raw as "lalapan" or } \\
\text { cooked to be sayur bobor, sayur bening, } \\
\text { oseng, or pecel. Older leaves as rabbit } \\
\text { forage. }\end{array}$ & 41 & 1.53 \\
\hline 3 & Anaphalis longifolia DC. & Sendura & $\begin{array}{l}\text { Flower kept as room freshner, dried as } \\
\text { ornamental, insect repellent, or sold in } \\
\text { nearby tourist attraction. }\end{array}$ & 36 & 1.40 \\
\hline 4 & Sonchus oleraceus $\mathrm{L}$. & Gembos & $\begin{array}{l}\text { Young leaves having medicinal } \\
\text { properties to cure hepatitis and other } \\
\text { liver diseases, facilitating breast milk. } \\
\text { Older leaves used as forage of rabbit. }\end{array}$ & 30 & 1.27 \\
\hline 5 & $\begin{array}{l}\text { Austroeupatorium } \\
\text { inulifolium (Kunth.) } \\
\text { R.X.King \& H.Rob. }\end{array}$ & $\begin{array}{l}\text { Malenggo, Maregol, } \\
\text { Sembung, Krenyo, } \\
\text { Maitan, Rikowot, } \\
\text { Tembulungan, Wedangan }\end{array}$ & $\begin{array}{l}\text { The wood used as firewood; leaves as } \\
\text { forage for goat; fragrant flower as } \\
\text { room freshner and mixed with sendura } \\
\text { to sold in nearby tourist attraction. }\end{array}$ & 24 & 1.80 \\
\hline 6 & $\begin{array}{l}\text { Crassocephalum crepidioides } \\
\text { (Benth.) S.Moore }\end{array}$ & $\begin{array}{l}\text { Lengko, Cangklong, } \\
\text { Menjangan }\end{array}$ & $\begin{array}{l}\text { Young leaves eaten, having medicinal } \\
\text { properties such as skin diseases, ulcer, } \\
\text { and face mask; older leaves as forage } \\
\text { of rabbit and guinea pig; mix of leaf } \\
\text { and root as soporific or cure of vitamin } \\
\text { B deficiency; flower as children's toy. }\end{array}$ & 18.5 & 1.40 \\
\hline 7 & $\begin{array}{l}\text { Leucanthemum vulgare } \\
\text { Lam. }\end{array}$ & Jenu, Jenung, Pitrem & $\begin{array}{l}\text { Flower used as mosquito repellant, } \\
\text { tonic, poultice for sore, or used as } \\
\text { ornamentals; root and stem used to } \\
\text { strengthen soil, prevent weeds } \\
\text { growing, as fish poison or insecticide. }\end{array}$ & 17.5 & 0.80 \\
\hline 8 & Ageratum conyzoides $\mathrm{L}$. & $\begin{array}{l}\text { Bandotan, Rema, Seprah } \\
\text { muda, Entut-entutan }\end{array}$ & $\begin{array}{l}\text { Young leaves eaten (cooked, not } \\
\text { usual), or used as forage of goat, leaves } \\
\text { as poultice for wound or slices; stem } \\
\text { latex as substitute of eucalyptus oil, } \\
\text { could prevent bleeding. }\end{array}$ & 17 & 0.80 \\
\hline 9 & $\begin{array}{l}\text { Erigeron karvinskianus } \\
\text { DC. }\end{array}$ & $\begin{array}{l}\text { Lonte sore, Pitrem } \\
\text { gunung, Jenu hitam, } \\
\text { Kembang benik, Otot- } \\
\text { ototan }\end{array}$ & $\begin{array}{l}\text { Whole part of the plant used to } \\
\text { prevent growth of other weeds or used } \\
\text { as ornamentals; leaves and flower as } \\
\text { poultice for sore; root used as } \\
\text { additional materials in tonic. }\end{array}$ & 13.5 & 0.73 \\
\hline 10 & Artemisia vulgaris $\mathrm{L}$. & $\begin{array}{l}\text { Sudamele, Sidamele, } \\
\text { Ambril }\end{array}$ & $\begin{array}{l}\text { Leaves used as insecticide and } \\
\text { herbicide, root brewed as tonic. }\end{array}$ & 10.5 & 0.67 \\
\hline 11 & $\begin{array}{l}\text { Acmella paniculata (Wall. } \\
\text { ex. DC.) R.K. Jensen }\end{array}$ & $\begin{array}{l}\text { Suweng-suwengan, Suket } \\
\text { jangkung, Bendotan }\end{array}$ & $\begin{array}{l}\text { Flower in the form of earrings for } \\
\text { children's toy; leaves as emergency } \\
\text { toothpaste. }\end{array}$ & 7.5 & 0.40 \\
\hline 12 & Youngia japonica (L.) DC. & Gembos kuning, Kenikir & $\begin{array}{l}\text { Leaves as forage or eaten (not usual); } \\
\text { flower as mosquito repellant and } \\
\text { ornamentals. }\end{array}$ & 5.5 & 0.71 \\
\hline 13 & $\begin{array}{l}\text { Ageratina riparia (Reg.) } \\
\text { R.M.King \& H.Rob }\end{array}$ & $\begin{array}{l}\text { Lakhar, Suket republik, } \\
\text { Repeblik }\end{array}$ & $\begin{array}{l}\text { Leaves used as subtitute of goat forage } \\
\text { in dry season; stem and leaves } \\
\text { fermented for } 15 \text { days as insecticide; } \\
\text { root rotted as soil fertilizer. }\end{array}$ & 3 & 0.53 \\
\hline 14 & Bidens pilosa $\mathrm{L}$. & $\begin{array}{l}\text { Kenul, Ketul, Ranjau, } \\
\text { Trucukan, Puyengan }\end{array}$ & $\begin{array}{l}\text { Leaves used as poultice/therapy of } \\
\text { skin diseases (itch); flower as children's } \\
\text { toy. }\end{array}$ & 2.5 & 0.13 \\
\hline 15 & $\begin{array}{l}\text { Dichrocephala integrifolia } \\
\text { (L.f.) Kuntze }\end{array}$ & $\begin{array}{l}\text { Rendeng, Semprang, } \\
\text { Semprah }\end{array}$ & Livestock forage. & 1.5 & 0.07 \\
\hline 16 & Erigeron sumatrensis Retz. & Jlantir & Alternative of livestock forage. & 1.5 & 0.20 \\
\hline 17 & $\begin{array}{l}\text { Tithonia diversifolia } \\
\text { (Hemsl.) A. Gray }\end{array}$ & - & Flower used as poultice of ulcer. & 1.5 & 0.07 \\
\hline 18 & Gnaphalium purpureum L. & - & - (no known uses) & 0 & 0.00 \\
\hline
\end{tabular}

*ICS: Index of Cultural Significance, ${ }^{* *}$ UV: Use Value 
the area. In Merapi-Merbabu Slopes, Boyolali there are two Asteraceae species found with relatively low UV; Tagetes erecta and Lactuca sativa with UV reached 0.1 and 0.07, respectively (Umartani \& Nahdi 2021) Other research conducted in Cibodas Biosphere Reserve showed prominent ICS on two Asteraceae species; Artemisia vulgaris (ICS: 98.32) and Bidens pilosa (ICS: 67.81) (Handayani et al. 2021).

Table 3 showed the known and recorded uses of Asteraceae species found in Mount Bisma by scientific exploration. Traditional knowledge on the uses of each species is found to contribute and enrich the recorded uses of Asteraceae species from studies conducted before. Rich traditional knowledge and scientific exploration should be combined to find the best utilization for the species. On the other hand, in the discussion on Asteraceae diversity, it is known that most species were recognized as alien species. Locals play important role in the population control of alien species by utilizing the plant optimally (Al Farishy \& Salamah 2021).

Table 3. Recorded uses of Asteraceae species found in Mount Bisma.

\begin{tabular}{|c|c|c|}
\hline No. & Species & Known Uses \\
\hline 1 & Galinsoga parviflora Cav. & \multirow{2}{*}{$\begin{array}{l}\text { Young leaves as food, treated as wild vegetables. Contains minerals; older } \\
\text { leaves as rabbit forage (Santosa et al. 2020) }\end{array}$} \\
\hline 2 & Galinsoga quadriradiata Rez. \& Pav. & \\
\hline 3 & Anaphalis longifolia DC. & Flower sold as souvenir (Utomo \& Heddy 2019) \\
\hline 4 & Sonchus oleraceus L. & $\begin{array}{l}\text { Edible (vegetables); treat anemia, liver infection, opium dependency, } \\
\text { diurethic, bacteri infection (Jimoh et al. 2011; Setyawati et al. 2015) }\end{array}$ \\
\hline 5 & $\begin{array}{l}\text { Austroeupatorium inulifolium (Kunth.) } \\
\text { R.X.King \& H.Rob. }\end{array}$ & $\begin{array}{l}\text { Phytotoxic, cytotoxic, and anti-fungal activity; leaveas as cure for cough } \\
\text { and fever, sore, and regulating fertility (Chandrasiri et al. 2015; Quattrochi } \\
\text { 2016) }\end{array}$ \\
\hline 6 & $\begin{array}{l}\text { Crassocephalum crepidioides (Benth.) } \\
\text { S.Moore }\end{array}$ & $\begin{array}{l}\text { Young leaves edible (vegetables), cure for gastrointestinal problem, wound } \\
\text { or slice, prevent bleeding; rabbit forage (Quattrochi 2016; Dairo \& } \\
\text { Adanlawo 2007) }\end{array}$ \\
\hline 7 & Leucanthemum vulgare Lam. & Ornamentals, mosquito repellent; leaves as food (Clements et al. 2004) \\
\hline 8 & Ageratum conyzoides $\mathrm{L}$. & $\begin{array}{l}\text { Skin disease and wound cure; slices, burnt, ulcer (Syamsuhidayat \& } \\
\text { Hutapea 1991) }\end{array}$ \\
\hline 9 & Erigeron karvinskianus DC. & Ornamentals, skin diseases (Quattrochi 2016; Sharmila et al. 2014) \\
\hline 10 & Artemisia vulgaris $\mathrm{L}$. & $\begin{array}{l}\text { Menstruation cycle, miscarriage, dysentry, nosebleed, intestinal bleeding } \\
\text { (Wijayakusuma et al. 1994) }\end{array}$ \\
\hline 11 & $\begin{array}{l}\text { Acmella paniculata (Wall. ex. DC.) } \\
\text { R.K. Jensen }\end{array}$ & $\begin{array}{l}\text { Emergency toothpaste, stomachaches, cure for fever (Quattrochi 2016; } \\
\text { Setyawati et al. 2015) }\end{array}$ \\
\hline 12 & Youngia japonica (L.) DC. & $\begin{array}{l}\text { Consumed as food, larvicidal activity (Rojas-Sandoval 2020; (Liu et al. } \\
\text { 2015) }\end{array}$ \\
\hline 13 & $\begin{array}{l}\text { Ageratina riparia (Reg.) R.M.King \& } \\
\text { H.Rob }\end{array}$ & Facilitate urination (Santosa et al. 2017) \\
\hline 14 & Bidens pilosa $\mathrm{L}$. & $\begin{array}{l}\text { Cure for fever, rheumatic, toothache, throat disease, skin diseases, snake } \\
\text { bites (Wijayakusuma et al. 1994; (Setyawati et al. 2015) }\end{array}$ \\
\hline 15 & Dichrocephala integrifolia (L.f.) Kuntze & $\begin{array}{l}\text { Analgesic, antibacterial, antiinflammation, cure for fever (Setyawati et al. } \\
\text { 2015; Quattrochi 2016) }\end{array}$ \\
\hline 16 & Erigeron sumatrensis Retz. & $\begin{array}{l}\text { Wound poultice, headaches, vertigo, TBC, asthma, rheumatic, } \\
\text { stomachaches (Silalahi et al. 2019) }\end{array}$ \\
\hline 17 & Tithonia diversifolia (Hemsl.) A. Gray & $\begin{array}{l}\text { Wound poultice, malaria, diarrhea, ornamentals, fever cure (Silalahi et al. } \\
\text { 2019; Setyawati, et al., 2015) }\end{array}$ \\
\hline 18 & Gnaphalium purpureum L. & unknown \\
\hline
\end{tabular}




\section{CONCLUSION}

Research in Mount Bisma discovered a total of 18 species of Asteraceae from two subfamilies and eight tribes, with the most abundant species was Ageratina riparia, dominating both the area observed due to its invasive nature. Locals of Sikunang Village recognized various uses of Asteraceae plants, such as consumption, livestock forage, medicine, sold in a tourist attraction, etc. G. parviflora and G. quadriradiata, known as mondrengan, scored the highest in ICS, that is 41. Meanwhile, malenggo (A. inulifolium), scored the highest in $\mathrm{UV}$, which is 1.80 . This study presented new information about Asteraceae species in Mount Bisma, implies that there are vast unexplored biodiversities in Mount Bisma and rich traditional knowledge on plant uses in its surrounding community. It needs further research in order to archive and preserve the biodiversity and the traditional knowledge.

\section{AUTHORS CONTRIBUTION}

B.K. collected and analysed the data and wrote the manuscript, P designed and supervised the research and revised the manuscript, R.S.K. supervised, revised, and finalized the manuscript.

\section{ACKNOWLEDGMENTS}

The author would like to thank Mr. Nur Amin, Chief of Sikunang Village for giving permission to conduct the research in Sikunang Village and local informants of Sikunang Village, Kejajar, Wonosobo for sharing their knowledge on the use of plants by participating in the survey. The manuscript is part of B.K. thesis under supervision of R.S.K.

\section{CONFLICT OF INTEREST}

The authors state that there is no conflict of interest in this research.

\section{REFERENCES}

Abdiyani, S., 2008. The Diversity of Understories Medicinal Plants in Dieng Plateau. Jurnal Penelitian Hutan dan Konservasi Alam, V(1), pp.79-92. doi: 10.20886/jphka.2008.5.1.79-92

Al Farishy, D. D. \& Salamah, A., 2021. Asteraceae Diversity and A New Record for Java at Citalahab Village, Gunung Halimun-Salak National Park. Jurnal Biologi Tropis, 21(2), pp.383-392. doi: 10.29303/ jbt.v21i2.2619

Backer, C. A. \& Brink, B., 1965. Flora of Java (Spermatophytes only) volume II, Groningen: Nordhoff.

Barbour, M. G. et al., 1987. Terrestrial Plant Ecology, 2nd edition, California: The Benjamin/Cummings Publishing Company.

Bhattacharyya, B., 2016. Botani Sistematik. 2nd edition, Jakata: Penerbit Buku Kedokteran EGC. 
Chandrasiri, I. et al., 2015. Phytotoxicity, cytotoxicity, and antioxidant activity of the invasive shrub Austroeupatorium inulifolium (Kunth.) R.M. King \& H.Rob. Ceylon Journal of Science, 44(1), pp.91-99. doi: 10.4038/ cjsbs.v44i2.7354

Clements, D. R. et al., 2004. The biology of Canadian weeds. 128. Leucanthemum vulgare Lam. Canadian. Journal of Plant Science, 84, pp.343-363. doi: 10.4141/P02-112

Compositae Working Group (CWG), 2021, Global Compositae Database, viewed 16 June 2021, from http://www.compositae.org, doi: $10.14284 / 411$

Cotton, C., 1996. Ethnobotany Principles and Applications, West Sussex: John Wiley and Sons Ltd..

Dairo, F. A. S. \& Adanlawo, I. G., 2007. Nutritional Qualiry of Crassocephalum crepidioides and Senecio biafrae. Pakistan Journal of Nutrition, 6(1), pp.35-39. doi: 10.3923/pjn.2007.35.39

Funk, V. A. et al., 2009. Classification of Compositae. In Systematics, Evolution, and Biogeography of Compositae. Vienna: International Association for Plant Taxonomy, pp.171-176.

Handayani, A. et al., 2021. Assessing the utilization of naturalized alien plant species by community to inform its management strategy: A case study in Cibodas Biosphere Reserve, West Java, Indonesia. Biodiversitas, 22(7), pp.2579-2588. doi: 10.13057/biodiv/d220705

Harijoko, A. et al., 2016. Geochronology and Magnetic Evolution of the Dieng Volcanic Complex, Central Java, Indonesia and Their Relationships to Geothermal Resources. Journal of Volcanology and Geothermal Research, 310, pp.209-224. doi: 10.1016/j.jvolgeores.2015.12.010

Jimoh, F. O. et al., 2011. Comparison of the Nutritive Value, Antioxidant, and Antibacterial Activities of Sonchus asper and Sonchus oleraceus. Resource of Natural Products, 5(1), pp.29-42.

Liu, X. C. et al., 2015. Larvicidal activity of the essential oil Youngia japonica aerial parts and its constitutents against Aedes albopictus. Zeitschrift fur Naturforschung, 70(1-2), pp.1-6. doi: 10.1515/znc-2014-4074

Megawati et al., 2017. Diversity of Asteraceae Family at Kalimpa'a Lake in Lore Lindu National Park. Natural Science: Journal of Science and Technology, 6(3), pp.239-253.

Nurpratama, M. I. et al., 2015. Detailed Surface Structural Mapping of the Dieng Geothermal Field in Indonesia. Proceedings World Geothermal Congress.

Nyuanti, A. S. et al., 2020. Risk Assessment and Management Recommendations of Invasive Species in Papandayan Mountain Natural Reserve, West Java. 3BIO: Journal of Biological Science, Technology, and Management, 2 (2), pp.39-46. doi: 10.5614.3bio.2020.2.2.5

Partomihardjo, T. \& Rahajoe, J. S., 2004. Pengumpulan Data Ekologi Tumbuhan. In Pedoman Pengumpulan Data Keanekaragaman Flora. Bogor: Pusat Penelitian Biologi - LIPI, pp.43-76. 
Purnomo et al., 2016. Spesies Tumbuhan Penyusun Vegetasi Lantai di Wilayah Restorasi Taman Nasional Gunung Merapi di Ngablak, Magelang, Jawa Tengah. Journal of Tropical Biodiversity and Biotechnology, 1(2), pp.6370. doi: $10.22146 /$ jtbb.15282

Quattrochi, U., 2016. World Dictionary of Medicinal and Poisonous Plants: Common Names, Scientific Names, Eponyms, Synonyms, and Etymology, Boca Raton: CRC Press.

Rojas-Sandoval, J., 2020, Youngia japonica (oriental false hawksbeard). Invasive Species Compendium CABI, viewed 10 June 2021, from: doi: 10.1079/ ISC.117921.20203483406.

Rugayah et al., 2004. Pengumpulan Data Taksonomi. In Pedoman Pengumpulan Data Keanekaragaman Flora. Bogor: Pusat Penelitian Biologi - LIPI, pp.5 -40 .

Santosa, D. et al., 2017. Kajian Keanekaragaman Jenis Tumbuhan Obat di Daerah Aliran Sungai Opak, Daerah Istimewa Yogyakarta. Majalah Farmaseutik, 13(1), pp.1-8.

Santosa, E. et al., 2020. Agroecology and Uses of Galinsoga parviflora as Indigenous Vegetables in Highland of Kuningan, Banjarnegara, and Wonosobo, Indonesia. Jurnal Agronomi Indonesia, 48(3), pp.339-347. doi: 10.24831/jai.v48i3.32800

Sardiwinata, J. S. et al., 2008. Cara Pengumpulan, Pembuatan, dan Pemeliharaan Koleksi Material Herbarium Pusat Konservasi Tumbuhan Kebun Raya Bogor, Jakarta: LIPI Press.

Setyawati, T. et al., 2015. A Guide Book to Invasive Alien Plant Species in Indonesia, Jakarta.: Research, Development, and Innovation Agency, Ministry of Environment and Forestry.

Sharmila, S. et al., 2014. Studies on the Folklore Medicinal Uses of Some Indigenous Plants among the Tribes of Thiashola, Manjoor, Nilgiris South Division, Western Ghats. International Journal of Plant, Animal, and Environmental Sciences, 4(3), pp.14-22.

Silalahi, M., 2016. Studi Etnomedisin di Indonesia dan Pendekatan Penelitiannya. Jurnal Dinamika Pendidikan, 9(3), pp.117-124.

Silalahi, M. et al., 2019. Tumbuhan Obat Sumatera Utara Jilid II: Dikotiledon, Jakarta: UKI Press.

Simpson, B. B., 2009. Economic Importance of Compositae. In Systematics, Evolution, and Biogeography of Compositae.Vienna: International Association for Plant Taxonomy, pp.45-58.

Sunarto et al., 2017. The Diversity Study of Asteraceae Family As Effort to Develop Ecotourism in Mount Lawu. Advances in Social Sciences, Education and Humanities Research, 79, pp.105-110. doi: 10.2991/icge16.2017.21

Syamsuhidayat, S. S. \& Hutapea, J. R., 1991. Inventaris Tanaman Obat Indonesia (I), Jakarta: Badan Penelitian dan Pengembangan Kesehatan. 
Tadesse, M., 2014. How to Study the Asteraceae (Compositae) with Special Reference to the Asteraceae of Fee. Ethiopian Journal of Biological Sciences, 13(Supp.), pp.91-101.

Turner, N., 1988. "The importance of a Rose": Evaluating the Cultural Significance of Plants in Thompson and Lillooet Interior Salish. American Anthropologist, 90(2), pp.272-290. doi: 10.1525/aa.1988.90.2.02a00020

Umartani, L. A. \& Nahdi, M. S., 2021. Ethnobotany of Community Food Plants on the Slopes of Merapi and Merbabu, Central Java, Indonesia. Proceeding International Conference of Science Engineering, 4, pp.56-63.

Utomo, A. B. S. \& Heddy, S., 2019. Etnobotani Edelweis (Anaphalis spp.) di Desa Ngadas, Taman Nasional Bromo Tengger Semeru. Jurnal Produksi Tanaman, 6(8), pp.1648-1654.

van Steenis, C. G. G. J., 2006. Flora Pegunungan Jawa, Jakarta: LIPI Press.

Walujo, E. B., 2004. Pengumpulan Data Etnobotani. In Pedoman Pengumpulan Data Keanekaragaman Flora. Bogor: Pusat Penelitian Biologi - LIPI, pp.77-92.

Wijayakusuma, H. M. H. et al., 1994. Tumbuban Berkhasiat Obat di Indonesia Jilid I, Jakarta: Penerbit Kartini. 